Review

\title{
Critical Overview on Organic Legislation for Animal Production: Towards Conventionalization of the System?
}

Pantelis Zoiopoulos ${ }^{1, \dagger}$ and Ioannis Hadjigeorgiou ${ }^{2, \dagger, *}$

1 Laboratory of Animal Science, School of Management of Natural Resources and Enterprises, University of Ioannina, 2 Seferi Street, Agrinio GR-30100, Greece; E-Mail: pzoiopul@cc.uoi.gr

2 Laboratory of Nutrition Physiology and Feeding, Faculty of Animal Sciences \& Aquaculture, Agricultural University of Athens, 75 Iera Odos, Athens 11855, Greece

$\dagger$ These authors contributed equally to this work.

* Author to whom correspondence should be addressed; E-Mail: ihadjig@aua.gr; Tel.: +30-210-5294-416; Fax: +30-210-5294-413.

Received: 28 May 2013; in revised form: 25 June 2013 / Accepted: 11 July 2013 /

Published: 17 July 2013

\begin{abstract}
Adoption of organic animal production legislation, particularly at the Community level, is done with a spirit of compromise and an attempt to reach consensus. In this sense, legal tools are used to solve technical problems so that an appreciable number of derogations (exceptions) are introduced. These may allow the use of certain feed additives, tethered animals or even application of castration. However, derogations should be avoided in legislation where harmonization is pursued, since they bring about distortion in the marketing of organic products. The validity of these derogations has expiry dates. However, at least the EU was hesitant to proceed with the necessary amendments to lift these derogations so that eliminate ambiguities and block loopholes. In turn, mention is made to geographical issues raised from the exceptions question posed again with the new EU Regulations. Furthermore some thoughts are expressed concerning the relationship between setting standards and the crucial role of values in agriculture, organic in particular, social aspects and pursued policy. Finally, the essential feature of this work is that derogations in legislation inevitably lead to conventionalization of organic animal production, which necessitates the clear definition of "organic". To substantiate this, relevant arguments are put forward.
\end{abstract}

Keywords: organic; animal farming; legislation; values in agriculture; conventionalization 


\section{Introduction}

Farm animals and feedstuffs are the basis of the production of safe food of animal origin [1]. In the face of world population increase, agricultural science as Research and Technology responded to this challenge by inventing new materials and methods of application. However, the abuse and misuse of these materials i.e., fertilizers and pesticides for plant as well as additives and medicines for animal production, involves an element of risk for animals, man as a consumer, and also the environment. These risks have stimulated the concern of the public, which in turn demand a "cleaner" agriculture [2]. In this respect, the term "organic" has emerged.

The world market of organic food is constantly growing and it is currently estimated at about 45 billion Euros [3]. The largest growth of organic agricultural land was in Europe, where the area under organic crops increased by 0.8 million hectares and is measuring now 10 million hectares ( 9 percent compared with 2009). Compared with 2009, the market increased by roughly eight percent in Europe and the United States. Although the leading market is still the United States with 20.2 billion euros, Europe is very close with 19.6 billion euros [3]. In Europe, Germany leads at 6 billion euros, followed by France ( 3.4 billion euros) and the United Kingdom ( 2 billion euros). Actually, consumers in Europe select organic food products because they are convinced that they support their health, they have less impact on the environment and the production methods respect animal welfare principles [4].

At the beginning, research on organic farming dealt with plant production [5], and later also turned to organic animal production [6]. Nowadays, research on the organic livestock system, where mainly the present paper focuses, has become very active indeed [7-13]. Organic farming has been promoted, at the political level, as the ideal model for rural development in Europe, integrating small scale food production with environmental considerations. However, at the core of organic farming are production standards, which distinguish it from other types of farming. An examination of policy development for the organic sector focuses primarily on regulatory arrangements [14]. It is apparent that technology barriers crucially depend on how "organic" is defined, and thus, the importance of organic rules and regulations is shaping the practices of organic production. In addition, organic standards provide added credibility to organic products in the eyes of the consumer. Although the latter may not have a full understanding of regulation, a key component in the success of organic production is market identification and reliability. Without unified organic standards, organic markets are plagued with confusion over the definition of "organic", which affects consumer confidence. Moreover, in contrast to the general assumptions, organic farms in Europe measure larger average sizes and lower rates of labor intensity than their conventional counterparts, casting doubts on the efficiency of organic farms to allow family farmers to remain in the rural areas as high-value farmers [15].

The paper is structured as follows. First, the complexity of the subject, as well as the reasons of the delay in issuing a relevant piece of Community legislation for the production and marketing of organic animal foods, are given. Second, the significance of speed observed and intergovernmental compromise that accelerated the adoption of legislation are quoted. Thirdly, a section is dedicated to the role of derogations introduced to solve technical problems and speed up the procedure for the adoption of legislation. Derogation is a legal term meaning a lessening or impairment of power or authority. In addition, the paper focuses on the confusion brought about by derogations in interpreting various provisions of the legislation, pointing out at the same time to the hesitance noticed by the side 
of the Community in lifting derogations when expiry dates had been reached. Furthermore, a section is devoted to the new Community organic Regulations in force from 1 January 2009. Mention is also made to emerging geographical issues, related to the exceptions question posed again with the new Regulations. Also, special reference is made to the risk for alternative agriculture switching to conventionalization and the paper concludes with some policy implications along with thoughts for a way out from the problem and recommendations for further work, taking into account the role of values in agriculture. It should be stressed that reference to provisions of the Community legislation in the present paper is only indicative. For the exact wording, the reader is directed to consult the Official Journal of the European Union. Finally, the overall aim of the present study is to focus on the importance of the policy element involved and to place it in the center of the regulatory activity looking at it from a technical scientist's point of view.

\section{Complexity and Delay}

The authors of the present paper focus on developments in EU legislation, firstly because EU is a big market by itself having numerous customers all over the world, in trading with Third countries, and secondly, being citizens of the EU, we have followed over the years the efforts towards formulating a harmonized organic animal production legislation. This does not necessarily mean that other countries do not experience similar problems while trying to define "organic" in their own territory [16]. Regulation 2092/1991 for organic plant production [17] was the first legislation developed for organic farming. This piece of European Union (EU) legislation issued in 1991 provided that the Council had to put forward proposals in four years, i.e., before June 1995, concerning the principles for, and specific inspection measures covering organic production of livestock. On the contrary, legislation for organic livestock production was adopted after long delay. It took the EU another four years (eight in total) to issue Council Regulation (EC) 1804/1999 for organic animal production [18]. Nevertheless, the text was agreed quickly to satisfy public concerns, because a number of adverse events, had occurred in the human food chain, which were related to foods of animal origin and were front-page newspaper stories. This was reflected in the preamble but also in the "feeding" and "disease prevention" section of the EU organic livestock legislation. Council Regulations (EEC) 2092/1991 [17] and (EC) 1804/1999 [18] constituted the basis for the agri-food sector to respond to increasing demands for organically produced food across Europe. Based on certain guidelines, organic livestock farming aims at establishing environmentally friendly production, sustaining animals in good health, realizing high animal welfare standards, and yielding products of high quality. However, there is something qualitatively different about the organic livestock legislation, which sets it apart from the crop case. In fact it has different characteristics (more difficult to regulate) and highlights different policy themes and concerns. In other words, livestock production without the use of feed additives and medicines, is a much more difficult affair compared to that of organic crop production (without fertilizers and pesticides) since the term "chemical" in the former case, appears to be more critical and delicate issue.

Because of the prohibited use of chemically synthesized allopathic veterinary medicinal products or antibiotics for preventive treatments, the organic livestock system contains a greater element of weakness, vulnerability, risk and cost in tackling epidemic problems [2]. This is because the production 
unit, namely a cow, sow or ewe, has apparently higher value than in the case of plants, i.e., an olive tree, a cotton or sugar beet plant. It should be underlined at this point that the subject appears to be more complex, since, for example in the case of the use of medicine in organic animal farming great economic interests are involved either for allopathic or homeopathic medicines, which lose or gain a big share of the market respectively. It should be stressed also that organic farming started as a movement and whereas some countries first had organic standards made and respected by local organizations and then by national governments, gradually the organic production was lifted in a framework of EU, where uniformity is ruling. It is important one to understand how the organic actors took decisions and were confused sometimes. In the mid 1990s, the International Federation of Organic Agricultural Movement (IFOAM) published the basic principles that should govern the organic animal production system. Among others, these principles included provisions on conversion of land and animals from conventional to organic, feeding, disease prevention, husbandry, manure handling, available range areas and housing. The EU legislation for organic livestock production, issued a few years later, was based on similar principles. However, the great difference between IFOAM [19] and the EU is that, although IFOAM's principles are simple recommendations and it is upon the good will of countries around the world to obey them, the provisions of EU Regulations constitute Community law, which takes precedence over the National law of each Member State in the Community.

\section{Time Frames and Compromise}

It should be underlined that, the EU was delayed in adopting legislation on organic animal production compared to that on plants, and it was only the accidents and big issues that occurred in the food chain in the late 1990s, that accelerated adoption procedures. These events, which had their origin in animal nutrition and feeding sector, included the Bovine Spongiform Encephalopathy (BSE) scandal with infected meat meals, as well as the dioxin episode [20] with contaminated fats in animal diets. They also included the issue of recombinant Bovine Growth Hormone (rBGH) [21] and that of the controversy over microbial cross-resistance. The latter led to the banning of a series of antibiotics used in animal nutrition. Finally, a relevant issue was that of the dichotomy of opinion over Genetically Modified Organisms (GMOs), where most of them fall within the area of animal production, as raw materials destined for feedingstuffs, e.g., maize and soya [22-24] not forgetting GM-farm animals.

The finally agreed text of Council Regulation (EC) 1804/1999 [18], due to pressure from the adverse events mentioned above, was the result of various compromises between EU Member States. To understand the need for a compromise, one has to realize that there were two "apparent" goals of the Community legislation for organic animal production: (1) securing safety for farm animals and the consumer, and (2) protecting the environment. However, there were also two "hidden" goals of the relevant legislation: (a) to avoid discouraging breeders switching to organic farming due to the stringent character of the initial legislation, and (b) to satisfy the interests of EU Member States having different animal production practices, by ensuring each State has a good share of the international market of organic products. In fact, when USDA (United States Department of Agriculture) released its second draft of the National Organic Standards, some advocates of organic farming thought the standards were too strict, possibly discouraging rather than encouraging farmers to grow organic crops [16]. 


\section{Plethora of Derogations}

Acting under public pressure and in order to achieve the afore-mentioned goals, the EU necessitated introducing a great number of derogations, especially in the beekeeping sector. Derogation, as mentioned earlier, is a legal term, meaning a lessening or impairment of power or authority. In other words, it is an exception from an obligation. Derogation is something to be avoided in legislation, since it undermines harmonization and could create serious problems in practice. To give an example of derogations one would quote that in the very crucial section of "feeding" in Council Regulation (EC) 1804/1999 [18], paragraph 4.2 of Annex 1B stated, "Livestock must be fed on organically produced feedingstuffs". However, paragraphs 4.4, 4.7, 4.8, 4.13, 4.14, 4.15 and 4.16, by way of derogation permitted, under certain conditions, the use of feeds of conversion stage, and conventional feeds in given amounts as well as certain feed additives. Particularly, the use of chemically or biotechnologically produced feed additives in organic animal production was not envisaged.

Further weak points of Council Regulation (EC) 1804/1999 [18] included sentences such as: "vitamins are permitted if authorized under the additive Council Directive 1970/524/EEC (authors' note: the additive Directive for conventional animal feeding at the time) preferably derived from materials occurring naturally in feedingstuffs", or "livestock must be reared preferably using feed from the unit", or "livestock must be fed predominantly with self-produced feeds". The words "preferably" and "predominantly" admit more than one interpretation, and are vulnerable points in a piece of legislation, since they lead to non-quantifiable, thus non-uniform, situations when applying legislation in agricultural practice. Another sentence of Council Regulation (EC) 1804/1999 [18] read: "operations such as dehorning...must not be carried out systematically in organic farming". How can the words "not systematically" be applied uniformly in practice? In addition, what about another provision: "physical castration is allowed in order to maintain the quality of products and traditional production practices, but only under the conditions of paragraph 6.12" (authors' note: Paragraph 6.12 stated that operations should be carried out at an appropriate age, by qualified personnel and any suffering to animals must be reduced to a minimum). Although, there is also welfare issue involved if you do not castrate animals, i.e., intact males may be more aggressive and there is a risk of immature females being mated, what about permission of castration with organic livestock for traditional product quality, when welfare is a central component of organic livestock production?

We should point out the significance and problems of such great numbers of derogations. Some authors have hinted problems with misleading provisions of organic livestock legislation [25,26]. It appears that there are contradictions between ideas and practice i.e., the reductionism of organic standards, the limitations of private organic certification, and the widespread practice of input-substitution. The standards of organic agriculture contain a number of contradictions and inconsistencies and many of the contradictions arise because of the nature of the standards, which inevitably cannot perfectly capture the idea they are meant to represent. Over time, these contradictions could be exploited to weaken standards and undermine arguments about the benefits of organic methods. The push towards increasing market sales has resulted in ongoing pressure in the certification community to relax standards in order to maintain members and in reluctance to publicly implement enforcement measures. Additionally, USDA in 1997, suggested standards that directly contradicted current organic practice, with an attempt to weaken the standards in order to break down barriers to entry for large 
agribusiness firms and to increase opportunities for profits. USDA concluded that deeper changes in social, scientific, political and economic relations are required to overcome these contradictions. In that case, many organic farmers were protesting USDA's loosening of standards [16].

\section{Hesitance and Confusion}

Derogations in Council Regulation (EC) 1804/1999 [18] had expiry dates. In substance, they transferred the solution of the problems to the future. However, when time was approaching for lifting the derogations, the EU appeared to be hesitant to introduce the necessary changes to organic livestock legislation. Some examples of inconsistency are given:

(1) With Commission Regulation (EC) 1517/2007 an extension until 31 December 2008 was given to feed manufacturers, so that operations may take place for organic feeds using the same equipment with conventional ones, provided that separation in terms of time as well as cleaning before use is guaranteed [27]. This exception continues with the new Regulation (EC) 834/2007 in force from January 1, 2009.

(2) With Commission Regulation (EC) $2277 / 2003$ the provision that for poultry, the feed formula used in the fattening stage should contain at least $65 \%$ cereals was deleted [28].

(3) With Commission Regulation (EC) 1916/2005, the prohibition expiring 31/12/2005 was lifted and synthetic vitamins identical to natural vitamins are given to monogastric animals and A, D and E to ruminants, with prior authorization from the competent authority of the Member State [29].

(4) With Commission Regulation (EC) 699/2006: "in the light of concerns about the spread of avian influenza, poultry may be kept indoors where restrictions, including veterinary restrictions, prevent or restrict access of poultry to open-air runs. Where poultry are kept indoors they shall permanently have access to sufficient quantities of roughage and suitable material in order to meet poultry's ecological needs" [30]. However, with this derogation, which has not been lifted up till now, the "extensive" element of housing conditions with free-range open-air exercise in outdoor areas of $4 \mathrm{~m}^{2} /$ broiler is loosening.

In addition, permission had been given for the use of additives such as sodium nitrite and potassium nitrate in the preparation of organically produced meat products. Finally, even very recently [31] the EU allowed the use of limited amounts of non-organic protein feed of plant and animal origin for organic livestock for years 2012, 2013 and 2014 included, where farmers are unable to obtain protein feed exclusively from organic production.

With all these derogations and the interests involved, it appears that the purpose of EU legislation for organic animal production is rather confusing. A number of provisions are ambiguous, whereas the overall impression from a technical point of view is that the clarity one would expect from EU legislation on organic livestock is lost. In addition, it is confusing that additives such as vitamins produced either chemically or by fermentation, are allowed in the organic livestock system. In this way, although we think of organic animal keeping as "extensive" system of production, EU has legislated for a confusing, rather "intensive", system, which deviates much from the expectations of the public for a "clean" agriculture. The core claim of the present paper is that, the necessity for intergovernmental compromise embodied in derogations weakened the purity of the standards under 
EU Council Regulation (EC) 1804/1999. In fact, a "veil" of stringent provisions and prohibitions characterizes Community legislation for organic animal production but, on the other hand, by introducing loopholes through a considerable number of derogations, it weakens the whole concept of organic farming. Therefore, a dilemma is emerging, from the human factor involved i.e., scientists, breeders, and above all the consumer_ — public and society in general—about the genuineness of the character of organic animal production under the Community legislation. The moral and ethical dimensions of good organic farming were emphasized especially with regard to animal husbandry [32]. Today, the basic problem is that the livestock industry is under pressure from society and due to the recent food crises we cannot reject this as unfair. Apart from technical, animal production problems also have a social character. It has been reported that with regard to standards, farmers have an economic incentive to cut corners to increase profits at the risk of ecological soundness. There are also instances where this kind of corner cutting crosses the line into fraud, and occasionally a struggle occurs in the production scene involving farmers and consumer politics in defining "organic" [16].

It should be added that, it was highly unexpected to see approved the use of certain additives in EU organic livestock legislation. Specifically, it is the authors' view, that the enzymes opened the loophole for other additives to enter. However, what was the reason to allow the use of enzymes in organic animal feeding? Between food quality and protection of the environment, it seems that the most demanding and critical issue for the majority of EU Member States at the time was the latter. Animal feed, apart from being a supplier of nutrients is also an indirect environmental contaminant through its indigestible and not metabolizable part; namely feces and urine. The most serious pollutants from animal excreta are nitrogen and phosphorus. One of the most promising answers to this problem is the use of enzymes in feed. In general, the greater part of phosphorus in feeds of plant origin is in the form of insoluble phytates and it appears that the use of the industrially produced enzyme phytase with non-ruminants may have opened the door for other biotechnologically or chemically produced additives to enter the organic livestock production.

Some conflicts may appear in the organic farming, as to how and to what degree the different aims can be achieved. Conflicts may appear regarding the most appropriate practice and relation to the basic aspects of the behavior of livestock on the one hand and the risk of pollution on the other. These conflicts are reflected in the compromises of National or EU legislation, where regulations develop after intensive debate, and sometimes one gets the impression that livestock production, at least for some species, may be acceptable, but not always desirable in organic farming. In the long term, therefore, it seems important that different types of livestock production contribute directly to increasing fulfillment of the organic ideal on a National scale or at farm level. However, this point of view has scarcely been elaborated [25]. It is important to know that several derogations in EU legislation are effected only after the permission of the competent authorities in each Member State. Medicines, for example, could be used under certain conditions. One should take into account the role of competent authorities. The latter have to monitor a situation where certain ambiguous provisions have to be applied. For example, a critical case for the certifying body in Regulation (EC) 1804/1999 [18] referred to the exception of animal tethering-beyond any sense of welfare-based on a provision expiring on 31 December 2010. The exception would continue for the "small farms" and the certifying bodies should give a clear definition of what is meant by "small farms". In general, the great number of derogations in the Community law for organic animal production upsets the uniform implementation of 
legislation in agricultural practice, leading to distortion of the marketing of organic products. This necessitates the study of the relationships between politics, regulatory bodies, certifying agents and the definition of the "organic".

\section{More Recent EU Organic Legislation}

At the second half of the last decade two new fundamental pieces of Community legislation on organic production, including livestock, came into force from 1 January 2009. Firstly, Council Regulation (EC) 834/2007 [33] on the production and labeling of organic products, and repealing Regulation (EEC) 2092/1991 [17]. This, apart from crops and livestock, covers also aquaculture, which was not done with Regulation (EC) 1804/1999 [18]. It also takes into account risk assessment measures, where appropriate. Additionally, it includes the concept of a restricted list of products and substances such as non-organic feed materials, feed additives, processing aids and disinfectants, authorized by the Commission, which may be used in organic farming. Furthermore, it contains provisions referring to the production of processed feeds and foods, as well as criteria concerning products and substances used in processing. In addition, there is a crucial chapter titled "Flexibility", referring to exceptional production rules, whereas there are extensive chapters on labeling and control system, as well as trade of the EU with third countries. Finally, it establishes a regulatory Committee on organic production to assist the Commission. As regards the second new organic Regulation in force from 1 January 2009, i.e., Commission Regulation (EC) 889/2008 [34], this is laying down detailed rules for the implementation of the previous Regulation (EC) 834/2007 [33] including the introduction of the new EU logo for organic products.

However, and despite the detailed rules they are supposed to introduce, the new Community Regulations did not lift any of the aforementioned derogations existing in Regulation (EC) 1804/1999 [18] as amended. In fact, in these Regulations, the term "derogation" changed to that of "exception". However, it appears to move far from the initial expectations of the consumer for a genuinely practiced organic farming. In this respect, on the grounds that differences exist in local climatic or geographical conditions, specific husbandry practices and stages of development, competent authorities of Member States may continue authorization of the tethering of cattle and of exceptions granted to livestock producing holdings, up to 31 December 2013, for housing conditions and stocking density, expiring otherwise on 31 December 2010.

\section{Geographical Questions}

Dunn [35], using as metaphor the clever term "Trojan pig", introduces the geographic dimension into the field of setting standards, including food safety standards. He stresses that standards have become a key tool in the governance of the world economy, and that the drive to harmonize these standards on a global scale is supposed to reduce technical barriers to trade and create conditions for fair and free trade. However, it is important to realize that the EU legislation is an administrative interpretation of the ideas of organic farming, when in their scope have wider goals, mainly originally identified and developed in the individual countries [25]. It should be mentioned at this point that diversity between EU countries, regarding the view on organic animal farming, is enormous. Furthermore, and in order to take an organic development, the actors, peasants and farmers, need to 
take ownership taking the lead in line with pushing for food and seed sovereignty. Southern Europe constitutes a distinct environment for livestock farming compared to that of the rest of the European continent [36]. The keeping of farm animals, sheep and goats in particular, in countries round the Mediterranean basin has been extensively studied [37-40]. The potential contribution of organic farming, with a view to increasing sustainability of Mediterranean small ruminant livestock systems, has been also reviewed by Ronchi and Nardone [41]. As regards the exceptions question posed again with the new organic Regulations (EC) 834/2007 [33] and (EC) 889/2008 [34], it should be stressed that these influence the fairness of competition in organic animal farming between Mediterranean and Northern European countries. It is obvious that regions which make use of the allowed looser provisions of the law, regarding the utilization of heavy buildings, special (more intensive) husbandry practices, feed additives etc. can produce quantitatively more, cheaper and in shorter period, animal products with a better feed conversion ratio. The exception for the tethering of animals, which now with Regulation (EC) 889/2008 [34] has been extended up to 31 December 2013, was then, from the very beginning, the result of a political compromise between Northern and Southern European countries. Northern European regions require heavier building constructions to tackle problems from adverse climatic conditions in winter. The organic Community law, as it stands with plethora of exceptions, seems to favor an "intensive" animal farming system, whereas organic production by definition corresponds to an extensive one. Small ruminants in the Mediterranean countries are kept extensively even under the conventional system [42], which is very close to being organic. The same is valid for the extensive (free-range) bovine and porcine conventional animal keeping in the Mediterranean countries. Conventional bee keeping also is very similar to the organic one in the area. Therefore, there is always a risk that Northern countries, making use of the exceptions in the EU organic law, are to produce cheaper organic animal products than that from the Mediterranean ones, so that they can flood the latter with organic products, even if those products are charged with transportation cost.

In addition to unfavorable implications of the exceptions in the EU organic legislation, the Mediterranean countries should take into account other provisions of the law as well. The availability of organic crops destined for animal feeds is a very critical issue for the area. Maximal utilization of forages, especially good quality lucerne, should be achieved [43], as well as alternatives to commonly used feed materials $[44,45]$. One important provision of the current Community organic law is that of prohibiting the use of chemically (solvent) extracted oil-seed meals in organic animal feeding. The dominant plant protein source in the area, particularly for non-ruminant animals, is solvent extracted soybean meal. The problem is enhanced since most of the soya available is a product of genetic modification, which is also prohibited in the Community organic legislation. The critical position of GMO feeds in animal nutrition has been established. This obviates the need for research in the field for finding alternatives to conventional protein sources. In general the two pillars supporting the mainstream livestock farming, namely the type of animal and its feed, are the ones which are going also to be crucial in organic farming and this was recently exemplified in research with poultry, broiler production in particular, when two genotypes were compared [46] and chickpeas were evaluated as substitute for soybeans [47]. 


\section{The Role of Values in Alternative Systems}

It should be stressed that there are societal interests in agricultural practices and their consequences pose a challenge to agricultural science. There is also a need to rethink the general methodology of agricultural research as well as reconsidering the role of values in science, since values play, and ought to play, an important role in science. In addition, the role of values is particularly evident with regard to organic farming, because special values and goals play an obvious and decisive role here, and because these values are clearly different from the values of mainstream agriculture [48,49]. We should not overlook the role of standard setting bodies and that there is a relationship between standards and values. It is important to realize that in the eyes of organic farmers, organic farming is based on fundamental values regarding nature, the environment, food production, farming and society. The basic guidelines or standards are thus attempts to find means that may help realize these values. Therefore the standards should be seen as temporary attempts to realize the values. Therefore, it is logical that guidelines should change over the years, allowing the basic ideas of values to be fulfilled in a better way. It is important to acknowledge the values of organic farming [25]. The social element involved in the organic livestock issue is very important. The organic market provides room and resources for social movement activity, and could be a catalyst for positive political and social change. In addition, the growing organics business can be a source of funds for activities such as research [16]. Furthermore, it allows everyone involved in organic farming a quality of life, which meets their basic needs, including adequate returns, work satisfaction and a safe working environment [25].

The adoption of organic animal production as a goal is a political option. However, the achievement of this goal in practice includes a technical component as well. The EU policy for "cleaner" animal production, due to the politics prevailing, namely the aforementioned interests involved and compromises, resulted in a legislation that lost its initial genuine character. To remedy this situation, the important role belongs equally to consumers, farmers, scientists and politicians. With regard to changes and improvements needed in order to make progress, it should be underlined that an examination of policy development for the organic sector focuses primarily on regulatory arrangements [14]. One way out of the problem may be to establish co-operation between those who govern, as well as farmers and consumers, since there can be a problem when industries self-regulate. The future of organics will be very much dependent on the motivation of end consumer, i.e., their ability to mobilize people as "organic consumers" by providing foods that satisfy their needs. Things do change but they require forthright actions. The banning of antibiotics used in animal nutrition, and the moratorium concerning the circulation of GMOs within EU territory some years ago, could serve as examples in this case.

The organic sector is offered as a site for disagreement over values. Standards are not simply technical or value neutral but embody specific values of those who set them, whether politicians or technocrats. Compromise through intergovernmental bargaining has weakened the "pure" organic position, especially by governments keen to develop the organic markets by any means. The present article focuses on problems of the Community organic livestock legislation. However, it should be pointed out that authorities of countries around the world also experienced similar problems. Information available for USDA [50], Australia and New Zealand [51] alternative farming, refers to the organic plant sector, although organic agriculture is not a sector approach, but definitely a system approach. According to the above authors, the question pending in the United States corresponds to the 
definition of "organic", and this obviates the importance of organic rules and regulations in shaping the practice of organic production. Similarly, in Australia and New Zealand the question of just what makes food "green" continued to be a source of social conflict. Organic livestock farming is a challenge, not only for the farmers, but also for agricultural research and interdisciplinary work. In this respect, socio-economic aspects concerning the acceptance of organic livestock production and the impacts of different agricultural strategies should be investigated [2]. Because of the objectives and the complexity of organic farming, it is necessary to focus on the need for appropriate development of research and advisory service dedicated to this. It should be pointed out that there is a need for better interaction between mainstream agricultural research and research groups specializing in areas of importance for organic farming. However, it is a matter of debate as to what extent research dedicated to organic farming problems should be integrated into existing research bodies or be conducted in separate bodies [25]. In any case, epidemiological studies to evaluate risk factors, as well as socio-economic investigations concerning the acceptance of organic livestock should be pursued. In addition, the elaboration of objective methods and indicators for on-farm animal welfare assessment should be further studied [8].

\section{Commenting on the "Conventionalization" Hypothesis}

The conventionalization debate on organic farming was first surfaced by Buck et al. [52], following a study of the California organic sector. Various researchers all over the world took part and placed themselves on this debate [53-60]. In particular, Lockie and Halpin [56] as well as Hall and Mogyorody [53], stated that conventionalization of organic farming does not exist in Australia and Ontario, Canada, respectively, whereas Best [59] reported that this situation operates to some extend in Germany. Furthermore, Guthman [50] quoted that several farms in California were abandoning the more sustainable and marketing practices of organic agriculture.

Darnhofer et al. [61] produced recently an excellent and comprehensive review on the critical issue of conventionalization of organic farming practices. These authors analyzing the subject, mentioned that according to the conventionalization hypothesis, organic farming is becoming a slightly modified version of modern conventional agriculture, replicating the same history, resulting in many of the same social, technical and economic characteristics. These changes, among others, involve larger farms or more purchased non-farm inputs and resource substitution. These mechanisms have been noted both at the farm level as well as in the processing and marketing of the organic products.

Lockie et al. [51] reviewed the issue of case studies carried out to test the conventionalization hypothesis of organic agriculture in various places over the world. These researchers concluded that studies by Hall and Mogyorody [53], Lockie and Halpin [56], Jordan et al. [57] show that, among others, concentration and input substitution occur to a significant extent. In addition, case studies carried out in Europe, report trends and practices on organic farming that could indicate conventionalization process. In particular, the size of organic farms is increasing in Denmark [55] and Germany [59]. Flaten et al. [62] report, for later entrants in Norway, intensification of milk production due to a higher use of concentrates. In addition, Best [59] considers that later entrants in Germany, appear to be relatively less concerned about the environment. It is also interesting to know that De Wit and Verhoog [58] report conventionalization trends in organic pig and poultry production in the 
Netherlands. In this way, either in Europe or elsewhere, some organic farms employ such practices, which may not be sustainable, but are not explicitly prohibited by the standards [63].

In this sense, Darnhofer et al., [61] instead of using structural criteria to study the organic farming conventionalization practices, as it is done mainly by economists, they follow a sociologist's direction of assessment based on the organic principles and all these at the farm level. They argue that a number of "symptoms" that have been used to identify conventionalization at farm level, may not be reliable indicators, so they are not well suited to achieve a comprehensive assessment of the type and direction of changes to organic farming. They suggest instead the planning of assessment based "on the principles and values", which constitute the foundation of the system to check the "level of conventionalization" on individual organic farms and define various indicators and criteria to capture the changes.

However, even so, ideology is not a quantifiable term, or at least one very difficult to quantify. How could someone quantify honesty accurately? The authors of the present study, represent the technical scientist's view. The choice of developing the organic system in a country, may be a political decision, with strong both economic and social elements, but it has also a profound biological and technical character. One should bear in mind that the cultivated plant and the reared farm animal are living organisms, whereas even in this alternative extensive system you have to apply certain techniques in order to reach proficiency. The regulatory bodies work mainly at technical level, at least in the crucial area of controls and it is not always easy to apply certain provisions of the law, since several sentences may be interpreted in different ways, while at the same time all interpreters being correct. In addition, there are great difficulties involved in answering technical questions. It is very difficult, even at the certifying body's level, to detect, identify and quantify the presence in the diets or animal products of traces from prohibited ingredients such as processed animal proteins [64], GMO's [65] or undesirable substances such as mycotoxins [66] and dioxins [67].

The essential feature of the present work is the position taken by the authors that the most critical cornerstone in the building of organic legislation is the regulatory body itself, in other words the policy-maker. The arguments expressed above support that phrase. Humans are weak by their nature so that farmers under the pressure of the markets and the big agribusiness and supermarkets entering the organic field, and if the legislation allows it through derogations (in fact loop-holes), are inclined to "cut corners", switching gradually to conventionalization. Allen and Kovac [16] have referred to the influence of legal regulations, whereas Buck et al. [52] to the entry of conventionally based agri-business into the organic food chain. Guthman [56] reported that organic farming by itself cannot guarantee for its alternativeness and all depends on how "organic" is defined, thus suggesting the importance of organic rules in shaping the practices of organic production. De Wit and Verhoog [58] state that only normative values may function as a guide towards the future, inspiring practices in organic farming, as well as long term market perspectives and regulatory developments.

Unfortunately, this appears to be a very difficult task indeed. Padel et al. [63] worked on a Community project to assist regulatory bodies to develop a procedure for the integration of the ethical value base of organic farming into standards and regulations. However, as a result, the weak points of the Regulation, namely "derogations", were merely changed to the near term "exemption". All the people involved i.e., technical scientists, sociologists, economists, farmers, processors, consumers and policy makers should sit round the same table and force the latter to produce "crystal clear" provisions in the legislation by lifting ambiguities and confusion through a clear definition of "organic". This 
development, given the influence of the international trade, will require regulative action at international level as well. Otherwise, organic farming, inevitably will switch gradually to conventionalization.

\section{Conclusions}

The initial Community organic livestock legislation was adopted after long delay, due to the nature of the issue area, including complexity. Food crises of the time played a decisive role, and under public pressure, procedures for adoption were accelerated. It was the outcome of intergovernmental bargaining and negotiations, as well as tensions between the interests of a single market and fair competition. It was also the need to allow countries flexibility to adapt general rules to their own specific conditions, even at the expense of purity. It appears also that organic legislation is more about producing a free market than justified in terms of environmental sustainability. In order not to discourage breeders to join this alternative type of production at the outset, the avenue of exceptions was chosen, mainly through tactics using legal tools (derogations). However, this policy distorts the genuineness of the system. Derogations had expiry dates. During the lapsing years from adoption of Regulation (EC) 1804/1999 [18], in quite a number of cases, the EU showed hesitation, either by extending the deadline of derogations, or becoming more flexible (generous). This was not solved with the new organic Regulations (EC) 834/2007 [33] and (EC) 889/2008 [34], whereby exceptions are still valid. Geographical concern is raised due to the existence of such great number of exceptions in the EU Regulations, which may lead to unfair competition. It appears that the inspection body or authority of Member States is elevated to an arbiter of the situation, with the known weaknesses of the system. It is also apparent that a number of important aspects are related to this field such as policy to be pursued, future research activities and the social element involved.

With the last minute compromises, some deviation from the initial spirit of organic animal production was brought about, based on the interests of the countries involved. It should be underlined at this point that the "organic spirit" is as diverse as the history and it should be made clear that the "spirit" has many facets and different angles. The purpose of this paper is not mere criticism, but to improve the situation regarding the purity of organic animal production under the Community law. It is quite an achievement that a piece of legislation exists on this topic, but this needs to be improved via coordinated action by all parties involved, i.e., consumers, farmers, scientists and politicians, with gaps filled and ambiguities lifted, so that the foggy scenery will clear up and research activities in this topic be built on concrete ground. However, one should always bear in mind that organic farming may be an ideology but, in addition, a farm is an enterprise that farmers should approach with professionalism and not romanticism. Finally, it should be underlined that unless a crystal clear definition is given for the "organic" globally, organic farming inevitably, under the pressure it undergoes from the market (large agribusiness companies), will switch gradually to conventionalization, in other words it will lose its genuine character, and this will be a big loss for all those involved in for this much promissing alternative farming system.

\section{Acknowledgements}

We are grateful to the anonymous reviewers for their constructive and helpful suggestions on this manuscript. However, the authors alone are responsible for the contents of this paper. 


\section{Conflict of Interest}

The authors declare no conflict of interest.

\section{References}

1. Flachowsky, G.; Danicke, S. From Feed to Safe Food - Contribution of Animal Nutrition to the Safety of Food. In New Developments in Food Policy, Control and Research; Riley, A.P., Ed.; Nova Science Publications: New York, NY, USA, 2005; pp. 65-96.

2. Sundrum, A. Organic livestock farming: A critical review. Livest. Prod. Sci. 2001, 67, 207-215.

3. Willer, H.; Arbenz, M. Organic agriculture worldwide: Market growing, agricultural land remains steady. Available online: http://www.fibl.org/en/media/media-archive/media-archive12/ media-release12/article/organic-agriculture-worldwide-market-growing-agricultural-land-remainssteady.html (accessed on 28 May 2013).

4. Pino, G.; Peluso, A.M.; Guido, G. Determinants of regular and occasional consumers' intentions to buy organic food. J. Consum. Aff. 2012, 46, 157-169.

5. McSheehy, T.W. Nutritive value of wheat grown under organic and chemical systems of farming. Qual. Plant. Plant Foods Human Nutr. 1977, 27, 113-123.

6. Guinot-Thomas, P.; Jondreville, C.; Laurent, F. Comparison of milk from farms with biological, conventional and transitional feeding. Milchwissenschaft 1991, 46, 779-782.

7. Lu, C.D.; Gangyi, X.; Kawas, J.R. Organic goat production, processing and marketing: Opportunities, challenges and outlook. Small Rum. Res. 2010, 89, 102-109.

8. Müller-Lindenlauf, M.; Deittert, C.; Köpke, U. Assessment of environmental effects, animal welfare and milk quality among organic dairy farms. Livest. Sci. 2010, 128, 140-148.

9. Tsiplakou, E.; Kotrotsios, V.; Hadjigeorgiou, I.; Zervas, G. Differences in sheep and goats milk fatty acid profile between conventional and organic farming systems. J. Dairy Res. 2010, 77, 343-349.

10. Bernues, A.; Ruiz, R.; Olaizola, A.; Villalba, D.; Casasus, I. Sustainability of pasture based livestock farming systems in the European Mediterranean context: Synergies and trade offs. Livest. Sci. 2011, 139, 44-57.

11. Gomiero, T.; Pimentel, D.; Paoletti, M.G. Environmental impact of different agricultural management practises: Conventional vs. Organic agriculture. Crit. Rev. Plant Sci. 2011, 30, 95-124.

12. Mena, Y.; Nahed, J.; Ruiz, F.A.; Sanchez-Munoz, J.B.; Ruiz-Rojas, J.L.; Castel, J.M. Evaluating mountain goat dairy systems for conversion to the organic model, using a multicriteria method. Animal 2012, 6, 693-703.

13. Gabriel, D.; Sait, S.M.; Kunin, W.E.; Benton, T.G. Food production vs. biodiversity: Comparing organic and conventional agriculture. J. Appl. Ecol. 2013, 50, 355-364.

14. Greer, A. Policy networks and policy change in organic agriculture: A comparative analysis of UK and Ireland. Public Admin. 2002, 80, 453-473.

15. Konstantinidis, C. Organic farming and rural transformations in the European Union: A political economy approach. Available online: http://scholarworks.umass.edu/dissertations/AAI3545954 (accessed on 28 May 2013). 
16. Allen, P.; Kovach, M. The capitalistic composition of organic: The potential of markets in fulfilling the promise of organic agriculture. Agric. Human Values 2000, 17, 221-232.

17. Council Regulation No. 2092/91 on organic production of agricultural products and indications referring thereto on agricultural products and feedstuffs. Available online: http://faolex.fao.org/ docs/pdf/eur2355.pdf (accessed on 28 May 2013).

18. Council Regulation No. 1804/1999 of supplementing Regulation No. 2092/1991/EEC on organic production of agricultural products and indications referring thereto on agricultural products and foodstuffs to include livestock production. Available online: http://faolex.fao.org/cgi-bin/ faolex.exe?rec_id $=013502 \&$ database $=$ faolex\&search_type=link\&table=result $\&$ lang=eng $\&$ format _name=@ERALLIFOAM (accessed on 28 May 2013).

19. Principles of Organic Agriculture. Available online: http:/www.ifoam.org/sites/default/files/ ifoam_poa.pdf(accessed on 28 May 2013).

20. Covaci, A.; Voorspoels, S.; Schepens, P.; Jorens, P.; Blust, R.; Neels, H. The Belgian PCB/dioxin crisis-8 years later: An overview. Environ. Toxicol. Pharmacol. 2008, 25, 164-175.

21. DuPuis, E. Not in my body: rBGH and the rise of organic milk. Agric. Human Values 2000, 17, 285-295.

22. Zoiopoulos, P.E. Modified animal feeds should be put to the test. Nature 1998, 394, 823.

23. Toke, D.; Marsh, D. Policy networks and GM crops issue: Assessing the utility of a dialectical model of policy networks. Public Admin. 2003, 81, 229-251.

24. Costa-Font, M.; Gil, J.M.; Trail, W.B. Consumer acceptance, valuation of and attitudes towards genetically modified food: Review and implication for food policy. Food Policy 2008, 33, 99-111.

25. Hermansen, J.E. Organic livestock production systems and appropriate development in relation to public expectations. Livest. Prod. Sci. 2003, 80, 3-15.

26. Wilson, S. Feeding animals organically - the practicalities of supplying organic animal feed. In Recent Advances in Animal Nutrition; Garnsworthy, P., Wiseman, J., Eds.; Nottingham University Press: Sheffield, UK, 2001; pp. 161-172.

27. Commission Regulation No. 1517/2007/EC of 19 December 2007 amending Regulation No. 2092/1991/EEC on labelling requirements related to the organic production methods for feedingstuffs. Available online: http://eur-lex.europa.eu/LexUriServ/LexUriServ.do?uri= OJ:L:2007:335:0013:0013:EN:PDF (accessed on 28 May 2013)

28. Commission Regulation No. 2277/2003 amending Annex I and II to Regulation No. 2092/1991/EEC on organic production. Available online: http:/eur-lex.europa.eu/LexUriServ/ LexUriServ.do?uri=OJ:L:2003:336:0068:0074:EN:PDF (accessed on 28 May 2013).

29. Commission Regulation No. 1916/2005/EC of 24 November 2005 amending Annex II to Regulation No. 2092/1991/EEC on organic production. Available online: http://eur-lex.europa.eu/ LexUriServ/LexUriServ.do?uri=OJ:L:2005:307:0010:0011:EN:PDF (accessed on 28 May 2013).

30. Commission Regulation No. 699/2006/EC of 5 May 2006 amending Annex I to Regulation No. 2092/1991/EEC as regards conditions of access for poultry to open-air runs. Available online: http://eur-lex.europa.eu/smartapi/cgi/sga_doc?smartapi!celexplus!prod!CELEXnumdoc\&numdoc= 32006R0699\&lg=EN (accessed on 28 May 2013). 
31. Commission Implementing Regulation (EU) No 505/2012 of 14 June 2012 amending and correcting Regulation (EC) No 889/2008 laying down detailed rules for the implementation of Council Regulation (EC) No 834/2007 on organic production. Available online: http:// eur-lex.europa.eu/LexUriServ/LexUriServ.do?uri=OJ:L:2012:154:0012:0019:en:PDF (accessed on 28 May 2013).

32. Vos, T. Visions of the middle landscape: Organic farming and the politics of nature. Agric. Human Values 2000, 17, 245-256.

33. Council Regulation No. 834/2007/EC of 28 June 2007 for organic production labelling of organic products, repealing Regulation No. 2092/1991/EEC. Available online: http://eur-lex.europa.eu/ LexUriServ/LexUriServ.do?uri=OJ:L:2007:189:0001:0023:EN:PDF (accessed on 28 May 2013).

34. Commission Regulation No. 889/2008/EC of 5 September 2008 laying down detailed rules for the implementation of Regulation No. 834/2007/EC on organic production and labelling of organic products with regard to organic production, labelling and control. Available online: http:// eur-lex.europa.eu/LexUriServ/LexUriServ.do?uri=OJ:L:2008:250:0001:0084:EN:pdf (accessed on 28 May 2013).

35. Dunn, E.C. Trojan pig: Paradoxes of food safety regulation. Environ. Plan. A 2003, 35, 1493-1511.

36. Hadjigeorgiou, I.; Osoro, K.; Fragoso de Almeida, J.R.; Molle, G. Southern European grazing lands: Production, environmental and landscape management aspects. Livest. Prod. Sci. 2005, 96, $51-59$.

37. Boyazoglu, J.; Morand-Fehr, P. Mediterranean dairy sheep and goat products and their quality: A critical review. Small Rum. Res. 2001, 40, 1-11.

38. De Rancour, M.; Fois, M.; Lavin, M.P.; Tchakerian, E.; Vallerand, F. Mediterranean sheep and goats production: An uncertain future. Small Rum. Res. 2006, 62, 167-179.

39. Zygogiannis, D. Sheep production in the world and in Greece. Small Rum. Res. 2006, 62, 143-147.

40. Hadjigeorgiou, I. Past, present and future of pastoralism in Greece. Available online: http://www.pastoralismjournal.com/content/1/1/24 (accessed on 28 May 2013).

41. Ronchi, B.; Nardone, A. Contribution of organic farming to increase sustainability of Mediterranean small ruminant livestock systems. Livest. Prod. Sci. 2003, 80, 17-31.

42. Volanis, M.; Stefanakis, A.; Hadjigeorgiou, I.; Zoiopoulos, P.E. Supporting the extensive dairy sheep smallholders of the semi-arid region of Crete through technical intervention. Trop. Anim. Health Prod. 2007, 39, 325-334.

43. Laffi, G.; Pasini, P. Traceability with alfalfa dehydration chain. In Quality in Lucerne and Medics for Animal Production; Delgado, I., Lloveras, G., Eds.; Options Mediterraneennes: Paris, France, 2001; Volume 45, pp. 219-223.

44. Scerra, V.; Capparra, P.; Foti, F.; Lanza, M.; Priolo, A. Citrus pulp and wheat straw silage as an ingredient in lamb diets: Effect on growth and carcass and meat quality. Small Rum. Res. 2001, 40, 51-56.

45. Volanis, M.; Zoiopoulos, P.E.; Panagou, E.; Tzerakis, C. Utilization of an ensiled citrus pulp mixture in the feeding of lactating dairy ewes. Small Rum. Res. 2006, 64, 190-195.

46. Katogianni, I.; Zoiopoulos, P.E.; Adamidis, C.; Fegeros, K. Comparison of two broiler genotypes grown under the provisions of EU organic legislation. Eur. Poult. Sci. 2008, 72, 116-120. 
47. Katogianni, I.; Zoiopoulos, P.E.; Adamidis, C.; Fegeros, K. Substituting chickpeas for soyabeans in diets for broilers fattened according to the Community organic regime. Eur. Poult. Sci. 2008, $72,152-156$.

48. Alroe, H.F.; Kristensen, E.S. Towards a systemic research methodology in agriculture: Rethinking the role of values in science. Agric. Human Values 2002, 19, 3-23.

49. Kaltoft, P. Values about nature in organic farming practice and knowledge. Sociol. Ruralis 1999, 39, 39-53.

50. Guthman, J. Raising organic: An agro-ecological assessment of grower practices in California. Agric. Human Values 2000, 17, 257-266.

51. Lockie, S.; Lyons, K.; Lawrence, G. Constructing "green" foods: Corporate capital risk and organic farming in Australia and New Zealand. Agric. Human Values 2000, 17, 315-322.

52. Buck, D.; Getz, C.; Guthman, J. From farm to table: the organic vegetable commodity chain of northern California. Sociol. Ruralis 1997, 37, 3-20.

53. Hall, A.; Mogyorody, V. Organic farmers in Ontario: An examination of the conventionalization argument. Sociol. Ruralis 2001, 41, 399-422.

54. Guthman, J. Back to the land: The paradox of organic food standards. Environ. Plan. A 2004, 36, 511-528.

55. Frederiksen, P.; Langer, V. Patterns of resource use on Danish organic farms: Aspects of farm-based rural development. Int. J. Agric. Resour. Govern. Ecol. 2008, 7, 96-109.

56. Lockie, S.; Halpin, D. The conventionalization thesis reconsidered: Structural and ideological transformation of Australian organic agriculture. Sociol. Ruralis 2005, 45, 284-307.

57. Jordan, S.; Shuji, H.; Izawa, R. Conventionalization in the Australian organic industry: A case study of the Darling Downs region. In Sociological Perspectives of Organic Agriculture: From Pioneer to Policy; CABI: Wallingford, UK, 2006; pp. 142-156.

58. De Wit, J.; Verhoog, H. Organic values and conventionalization of organic agriculture. NJAS-Wagen. J. Life Sci. 2007, 54, 449-462.

59. Best, H. Organic agriculture and the conventionalization hypothesis: A case study from West Germany. Agric. Human Values 2008, 25, 95-106.

60. Guptill, A. Exploring the conventionalization of organic dairy: Trends and counter-trends in upstate New York. Agric. Human Values 2009, 26, 29-42.

61. Darnhofer, I.; Lindenthal, T.; Bartel-Kratochvil, R.; Zollitsch, W. Conventionalization of organic farming practices: From structural criteria towards an assessment based on organic principles. A review. Agron. Sust. Devel. 2010, 30, 67-81.

62. Flaten, O.; Lien, G.; Ebbesvik, M.; Koesling, M.; Valle, P.S. Do the new organic products differ from the "old guard"? Empirical results from Norwegian dairy farming. Renew. Agric. Food Syst. 2006, 21, 174-182.

63. Padel, S.; Röcklinsberg, H.; Schmid, O. The implementation of organic principles and values in the European Regulation for organic food. Food Policy 2009, 34, 245-251.

64. Van Raamsdonk, L.W.D.; von Holst, C.; Baeten, V.; Berben, G.; Boix, A.; de Jong, J. New developments in the detection and identification of processed animal proteins in feeds. Anim. Feed Sci. Tech. 2007, 133, 63-83. 
65. Marmiroli, N.; Maestri, E.; Gullì, M.; Malcevschi, A.; Peano, C.; Bordoni, R.; De Bellis, G. Methods for detection of GMOs in food and feed. Anal. Bioanal. Chem. 2008, 392, 364-384.

66. Binder, E.M. Managing the risks of mycotoxins in modern feed production. Anim. Feed Sci. Tech. 2007, 133, 140-166.

67. Commission Regulation (EC) No 152/2009 of January 2009 laying down the methods of sampling and analyses for the official control of feed. Available online: http://eur-lex.europa.eu/ LexUriServ/LexUriServ.do?uri=OJ:L:2009:054:0001:0130:EN:PDF (accessed on 28 May 2013).

(C) 2013 by the authors; licensee MDPI, Basel, Switzerland. This article is an open access article distributed under the terms and conditions of the Creative Commons Attribution license (http://creativecommons.org/licenses/by/3.0/). 